\title{
ISOLATION OF ACC DEAMINASE PRODUCING RHIZOBACTERIA FROM WHEAT RHIZOSPHERE AND DETERMINATING OF PLANT GROWTH ACTIVITIES UNDER SALT STRESS CONDITIONS
}

\author{
ATEŞ, Ö. ${ }^{*}-$ KIVANÇ, M. ${ }^{2}$ \\ ${ }^{I}$ Transitional Zone Agricultural Research Institute, Eskişehir, Turkey \\ ${ }^{2}$ Eskisehir Technical University, Faculty of Science, Department of Biology, Eskisehir, Turkey \\ *Corresponding author \\ e-mail:ozgurates@windowslive.com
}

(Received 27 $7^{\text {th }}$ Apr 2020; accepted $10^{\text {th }}$ Jul 2020)

\begin{abstract}
Salinity in agricultural lands is a major problem worldwide and the application of 1-aminocyclopropane-1-carboxylate (ACC) producing plant growth-promoting rhizobacteria (PGPR), is a good option to reduce the effects of salt stresses on plant growth and development. This study aims to isolate ACC deaminase producing PGPR and evaluate their effect on the growth and yield of wheat (Triticum aestivum L.) under salt stress of conditions. 21 ACC deaminase producing bacteria were isolated from wheat rhizosphere and the effectiveness of the isolates was determined by petri, jar and pot experiments. Pot experiments were established with 5 bacterial isolates (Bacillus cereus, Serratia odorifera, Lelliottia amnigena, Arthrobacter arilaitensis, Pseudomonas putida) and 4 different salt levels $\left(0.95,3.98,7.80,11.05 \mathrm{dS} \mathrm{m}^{-1}\right)$. ACC deaminase producing bacteria increased shoot and root length under petri and jar trial. Likewise, inoculation of PGPRs under salt stress conditions had a positive effect on wheat Sodium (Na), Potassium (K), Calcium $(\mathrm{Ca})$, Chlorophyll a and chlorophyll b contents compared to uninoculated control plants in pot trials. Inoculation of wheat with ACC deaminase producing PGPR alleviated the negative effects of salinity and increased plant growth. This study shows the vital role of rhizobacteria producing ACC deaminase increasing salt tolerance and eventually the development of wheat under salinity stress.
\end{abstract}

Keywords: plant growth-promoting rhizobacteria (PGPR), abiotic stress, salinity, ethylene, pot experiments

\section{Introduction}

Salinity is one of the most notable abiotic stress sources that affect agricultural systems and cause a decrease in the food supply in agricultural production. Salinity affects 80 million hectares of agricultural land worldwide (Munns and Tester, 2008) and saline soils increase approximately $7 \%$ per year (Tester, 2003). More than $6 \%$ of the total land that can be used for agricultural purposes is seriously affected by salt stress in arid and semi-arid regions around the world (Sarkar et al., 2018). Arid climates, low-quality irrigation water, and high temperatures with imbalances in the distribution of rain are among the main causes of soil salinity. Soluble salts accumulate in the plow layer in regions where the evaporation amount of plants is higher than the size of the leach fraction (Rajput et al., 2013). Salt deposits in the soil disrupt the physical and chemical balance of the soil and naturally adversely affect plant growth. In plants developing at high salt concentrations, reactive oxygen species, osmotic shock, ion toxicity, reduced nutrient uptake and reduction in leaf area are observed (Parihar et al., 2015). Increased soil salinity leads to a decrease in plant growth and crop yields as well as in microbial activity. Environmentally friendly, cost-effective and innovative 
approaches are needed to minimize the effects of salinity on agricultural soils and increase crop yields. The use of bacteria known as Plant Growth Promoting Rhizobacteria (PGPR) which increases plant growth in abiotic stress conditions is one of the most appropriate and sustainable approaches for alleviating the effects of salt stress (Yang et al., 2008; Sofo et al., 2015). PGPR can increase plant growth by reducing the effects of abiotic stresses, fixing nitrogen, producing plant hormones, dissolving phosphates in the soil and also producing siderophores that increase iron intake (Shanmugam and Kanoujia, 2011; Çakmakç1, 2016). Reduced the amount of ethylene produced under stress conditions, by 1-aminocyclopropane-1-carboxylate (ACC) deaminase containing PGPR is one of the most important mechanisms of alleviating salt stress (Singh et al., 2016). Ethylene is a gaseous form and is a very important plant hormone that is produced by almost all plants and plays a role in plant growth and differentiation. Ethylene at low concentration $\left(10 \mu \mathrm{g} \mathrm{L}^{-1}\right)$ plays a part in plant growth, seed germination, fruit maturing, flower shedding and root development. However, at high concentration $\left(25>\mu \mathrm{g} \mathrm{L}^{-1}\right)$ may cause root growth reduction and some plant process (Nadeem et al., 2010). A number of PGPR strains containing ACC deaminase which can break down the ethylene precursor ACC into ammonia and $\alpha$-ketobuyrate thereby reduce the level of ethylene in stressful plants (Ali et al., 2014; Glick, 2014). In recent years, ACC deaminase producing bacteria have been used to reduce the amount of ethylene produced by plants under stress conditions. Research has found that PGPR containing ACC deaminase increases plant growth in abiotic stress conditions such as heavy metal (Hassan et al., 2016; Grobelak et al., 2018), flood (Ravanbakhsh et al., 2017; Ali and Kim, 2018), drought (De Zelicourt et al., 2013; Erdogan et al., 2016; Carlson et al., 2020) salinity (Afridi et al., 2019; Tahir et al., 2019). This study aims to isolate acc deaminase-containing PGPR from wheat roots grown in saline soils and to determine their effects on wheat development under salt stress conditions in pot trials.

\section{Materials and Methods}

\section{Isolation of bacteria}

For isolation, 21 soil samples were collected from saline soils of Eskişehir province TURKEY in 2014. Soil samples were taken from wheat root rhizosphere and brought into the laboratory in plastic bags. Rhizopheric bacteria were isolated by serial dilution technique. Between $10^{-4}$ and $10^{-6}$ dilution was spread on DF salt minimal medium which ACC is used as a nitrogen source (Dworkin and Foster, 1958) and bacterial isolates were purified by repeated streaking. In laboratory, we prepared salt medium as follows (per $1000 \mathrm{ml}$ ) $6.0 \mathrm{~g} \mathrm{Na}_{2} \mathrm{HPO}_{4}, 4.0 \mathrm{~g} \mathrm{KH}_{2} \mathrm{PO}_{4}, 2.0 \mathrm{~g}$ glucose, $2.0 \mathrm{~g}$ gluconic acid, 2.0 g citric acid, 0.2 g $\mathrm{MgSO}_{4} .7 \mathrm{H}_{2} \mathrm{O}, 1 \mathrm{mg} \mathrm{FeSO}_{4} .7 \mathrm{H}_{2} \mathrm{O}, 124.6 \mu \mathrm{g} \mathrm{ZnSO}_{4} .7 \mathrm{H}_{2} \mathrm{O}$,

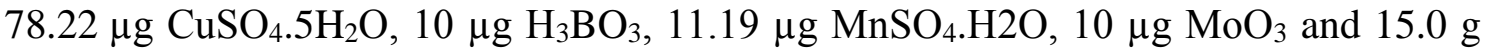
agar $(\mathrm{pH}$ 7.2). We prepared $300 \mathrm{ml} \mathrm{DF}$ salt medium autoclaved and after cooling $\left(>35^{\circ} \mathrm{C}\right.$ ) added $30 \mathrm{ml} 0.5 \mathrm{mM}$ ACC solution (filter sterilized). Purified ACC deaminase containing bacteria was stocked in LB medium and $20 \%$ glycerol at $-80{ }^{\circ} \mathrm{C}$.

\section{Characterization and identification of bacteria}

Characterization of bacteria used in pot experiments was done by 16s rDNA method. Genomic DNA isolated from bacteria and sequence analysis was performed by 
replicating DNA's 16s rDNA region by PCR (Barnawal et al., 2014). Nucleotide similarities were determined by NCBI-BLAST and gene bank numbers were obtained.

\section{Inoculation of seeds with bacteria}

Wheat seeds surface sterilized and coated with bacteria for further experiments. After wheat seeds were immersed to $95 \%$ ethanol for a very short time (5 seconds), kept in $2 \% \mathrm{HgCI}_{2}$ solution for $3 \mathrm{~min}$. Seeds washed 5 times with sterilized distilled water. Seeds immersed $3 \mathrm{~m} \mathrm{M}$ ACC solution for $5 \mathrm{~min}$. then kept in $30 \mathrm{~min}$ 24-h bacterial culture (Zahir et al., 2009).

\section{Petri experiments}

In Petri experiments, 5 bacteria coated seeds placed in sterile petri dishes containing sterile filter paper under sterile conditions. After a second filter paper to cover the seeds and five $\mathrm{ml}$ of sterile $5 \mathrm{dS} \mathrm{m} \mathrm{m}^{-1} \mathrm{NaCl}$ solution added to each petri dish. Petri dishes incubated seven days with $28 \pm 1{ }^{\circ} \mathrm{C}$ and shoot, root data recorded. The experiments conducted with three replication.

\section{Jar experiments}

In jar experiment, sterilized jars were used and conducted with 3 replication. 5 bacteria coated seeds were sandwiched between two sterilized filter paper which placed in $10 \mathrm{dS} \mathrm{m}^{-1} \mathrm{NaCl}$ containing $1 / 2$ strength Hoagland solution (Hoagland and Arnon, 1950). The jars were placed in the growth chamber at $25^{\circ} \mathrm{C}$, adjusted to 16 hours light and 8 hours dark for 21 days (Zahir et al., 2009). End of the jar trials shoot length and root length recorded.

\section{Pot experiments}

Pot experiments were carried out in the greenhouse of Eskişehir Transitional Zone Agricultural Research Institute Turkey to determine the effectiveness of selected bacterial strains for plant growth of wheat under different salt conditions. Soils were taken from the land and sieved through $2 \mathrm{~mm} 4.5 \mathrm{~kg}$ of plastic pots were filled from the homogeneous mixture (3:1 soil, sand). Pot mixture was analyzed for some physicochemical properties i.e. saturation $56 \%, \mathrm{pH}: 7.82, \mathrm{EC}: 0.95 \mathrm{dS} \mathrm{m}^{-1}$ organic matter: $1.44 \%$, extractable P: $4.12 \mathrm{mg} \mathrm{kg}^{-1}$ and extractable $\mathrm{K}: 120.38 \mathrm{mg} \mathrm{kg}^{-1} .40 \mathrm{~kg} \mathrm{ha}^{-1}$ phosphorus (together with sowing) and $180 \mathrm{~kg} \mathrm{ha}^{-1}$ nitrogen (half sowing and half at the beginning of tillering) were applied to the pots.

Pot experiments were planned at 4 different salt levels with $1,4,8,12 \mathrm{dS} \mathrm{m}^{-1}$ with 4 replications. The amount of $\mathrm{NaCl}$ calculated, dissolved in water and applied to the pots soils. Actual salinity was measured as $0.95,3.98,7.80$ and $11.05 \mathrm{dS} \mathrm{m}^{-1} .8$ bacterial grafted wheat seeds were planted in the pots and after germination, the seeds were diluted 4 plants. The experiment was carried out according to the factorial experiment design in randomized plots. In the experiment, irrigation was carried out twice a week with distilled water without drainage. $\mathrm{Na}, \mathrm{K}, \mathrm{Ca}$, chlorophyll a, and chlorophyll b were determined and analyzed. Data were analyzed by using SPSS version 25.0 (SPSS Inc., Chicago, IL, USA). differences among means were compared with Duncan multiple comparison tests. 


\section{Determination of leaf element contents}

The first leaves, just below the flag leaf, were collected and analyzed for each plant. Leaf samples collected from plants were washed with distilled water and dried for $65{ }^{\circ} \mathrm{C}$ 48 hours. The dried samples were ground and weighed into $0.25 \mathrm{~g}$ microwave tubes. $10 \mathrm{ml}$ of $\mathrm{HNO}_{3}$ mixture containing $20 \% \mathrm{HCIO}_{4}$ was added to the weighed sample and digested in the for 30 minutes. $\mathrm{Na}, \mathrm{K}$, and $\mathrm{Ca}$ were determined as $\mathrm{mg} \mathrm{g}^{-1}$ dry weight (DW) by ICP-OES (Optima 8000, PerkinElmer, USA) after completing $50 \mathrm{ml}$ of the digested liquid.

\section{Determination of chlorophyll $a$ and $b$ content}

To determine the amount of chlorophyll a and chlorophyll b in wheat leaves, $500 \mathrm{mg}$ fresh weight (FW) leaf were crushed in mortar in $90 \%$ acetone and centrifuged at $9000 \mathrm{~g}$ for 10 minutes. After centrifugation, the supernatant was completed to $50 \mathrm{ml}$ and measured at 645 and $663 \mathrm{~nm}$ in the spectrophotometer. Chlorophyll a (Eq.1) and chlorophyll b (Eq.2) contents were determined (Lichtenthaler, 1987).

$$
\begin{aligned}
& \text { Chlorophyll a }\left(\mathrm{mg} \mathrm{g}^{-1} \mathrm{FW}\right)=(11.75 \times \mathrm{A} 663-2.35 \times \mathrm{A} 645) \times 50 / 500 \\
& \text { Chlorophyll b }\left(\mathrm{mg} \mathrm{g}^{-1} \mathrm{FW}\right)=(18.61 \times \mathrm{A} 645-3.96 \times \mathrm{A} 663) \times 50 / 500
\end{aligned}
$$

\section{Results \\ Petri and jar experiments}

The data obtained as a result of the petri experiments showed that the root and shoot lengths of wheat which inoculated with ACC deaminase producing PGPR increased compared to the uninoculated control (Table 1). Inoculation with ACC deaminase containing bacteria significantly increased plant root and seedling length. The strain $20 / 1$ caused the maximum increase in root length with $74 \%$ compared to the uninoculated control. Strain $20 / 1$ was followed by strain $18 / 6$ with $54 \%$, strains $1 / 6$ and $11 / 5$ with $32 \%$ over the control. Among the isolates in the petri experiment, the highest shoot length was obtained from strain 17/4 with $43 \%$ over the control. Strain 10/6 and strain $1 / 6$ increased shoot length $41 \%$ and $35 \%$ compared to uninoculated control respectively.

The jar experiments were established with 9 bacterial isolates which were determined as a promising from the petri experiments. As a result of jar trials, length of root and shoot of wheat seeds inoculated with ACC deaminase containing strains increased compared to control (Table 2). Strain 21/4 caused maximum increase of root length (97\%) compared to uninoculated control. Strain 15/1 and strain 11/5 increased root length of $82 \%$ and $56 \%$ over the control, respectively. Similarly, strain 18/6 and 10/6 increased shoot length of $54 \%$ and $51 \%$ over the control, respectively. The maximum shoot length increase data obtained from strain $15 / 1$ with $60 \%$ compared to control.

\section{Pot experiments}

As a result of jar trials, pot experiments were established with strain 10/6, strain 11/5, strain 15/1, strain 18/6, strain 21/4 and 4 different salt levels which 0.95, 3.98, 7.80, $11.05 \mathrm{dS} \mathrm{m}^{-1}$. The bacterial isolates used for the pot experiments were identified as strain 10/6 Bacillus cereus 10/6, strain 11/5 Serratia odorifera 11/5, strain 15/1 
Lelliottia amnigena, strain 18/6 Arthrobacter arilaitensis, and strain 21/4 Pseudomonas putida (Table 3).

Table 1. Effect of ACC deaminase producing rhizobacteria on root and shoot length of wheat under $5 \mathrm{dS} \mathrm{m} \mathrm{m}^{-1} \mathrm{NaCl}$ in petri trial $(p<0.05)$

\begin{tabular}{c|c|c}
\hline Strain & RootLenght $(\mathbf{c m})$ & ShootLenght $(\mathbf{c m})$ \\
\hline Control & $5.85 \pm 0.42^{* *}$ & $4.98 \pm 0.21$ \\
$1 / 6^{*}$ & $7.70 \pm 0.27$ & $6.70 \pm 0.22$ \\
$2 / 5$ & $6.16 \pm 0.62$ & $6.01 \pm 0.50$ \\
$3 / 4$ & $6.02 \pm 0.48$ & $5.24 \pm 1.45$ \\
$4 / 2$ & $6.92 \pm 032$ & $6.82 \pm 0.72$ \\
$5 / 4$ & $6.15 \pm 0.47$ & $5.07 \pm 0.97$ \\
$6 / 1$ & $6.27 \pm 0.37$ & $6.50 \pm 0.61$ \\
$7 / 3$ & $5.19 \pm 0.12$ & $6.48 \pm 1.11$ \\
$8 / 4$ & $7.13 \pm 0.52$ & $6.60 \pm 0.48$ \\
$9 / 7$ & $6.29 \pm 1.14$ & $6.29 \pm 1.04$ \\
$10 / 6^{*}$ & $7.65 \pm 0.73$ & $7.02 \pm 0.31$ \\
$11 / 5^{*}$ & $7.70 \pm 0.29$ & $5.76 \pm 0.19$ \\
$12 / 1$ & $6.00 \pm 0.79$ & $5.15 \pm 0.71$ \\
$13 / 4^{*}$ & $7.47 \pm 0.56$ & $6.14 \pm 0.19$ \\
$14 / 2$ & $6.12 \pm 0.45$ & $5.01 \pm 0.21$ \\
$15 / 1^{*}$ & $7.02 \pm 0.30$ & $5.90 \pm 0.26$ \\
$16 / 1$ & $7.09 \pm .048$ & $6.42 \pm 0.39$ \\
$17 / 4^{*}$ & $7.50 \pm 0.39$ & $7.10 \pm 0.44$ \\
$18 / 6^{*}$ & $9.02 \pm 0.28$ & $6.09 \pm 0.13$ \\
$19 / 3$ & $6.12 \pm 0.77$ & $6.08 \pm 0.51$ \\
$20 / 1^{*}$ & $10.02 \pm 0.87$ & $6.30 \pm 0.51$ \\
$21 / 4^{*}$ & $7.47 \pm 0.21$ & $5.90 \pm 0.18$ \\
\hline
\end{tabular}

${ }^{*}$ Selected for jar trial ${ }^{* *}$ Average for third replicate \pm Std. Error

Table 2. Effect of ACC deaminase producing rhizobacteria on root and shoot length of wheat under $10 \mathrm{dS} \mathrm{m}^{-1} \mathrm{NaCl}$ in jar trial $(p<0.05)$

\begin{tabular}{c|c|c}
\hline Strain & Root Lenght $(\mathbf{c m})$ & Shoot Lenght $(\mathbf{c m})$ \\
\hline control & $6.80 \pm 0.75^{*}$ & $16.00 \pm 0.53$ \\
$1 / 6$ & $6.60 \pm 0.80$ & $19.45 \pm 1.15$ \\
$10 / 6^{\mathrm{a}}$ & $10.40 \pm 0.89$ & $24.20 \pm 1.07$ \\
$11 / 5^{\mathrm{a}}$ & $10.60 \pm 0.89$ & $21.60 \pm 2.60$ \\
$13 / 4$ & $7.60 \pm 0.96$ & $20.80 \pm 0.95$ \\
$15 / 1^{\mathrm{a}}$ & $12.40 \pm 0.96$ & $25.60 \pm 0.80$ \\
$17 / 4$ & $9.50 \pm 0.83$ & $20.80 \pm 2,02$ \\
$18 / 6^{\mathrm{a}}$ & $9.20 \pm 0.43$ & $24.60 \pm 1.10$ \\
$20 / 1$ & $8.40 \pm 0.60$ & $23.20 \pm 1.28$ \\
$21 / 4^{\mathrm{a}}$ & $13.40 \pm 0.30$ & $23.60 \pm 1.23$ \\
\hline
\end{tabular}

${ }^{\text {a }}$ Selected for pot trial ${ }^{*}$ Average for third replicate \pm Std. Error 
Table 3. Identification of strains

\begin{tabular}{c|c|c|c}
\hline Strain No. & Species & Accession No & Similarity (\%) \\
\hline $10 / 6$ & Bacillus cereus & KP027636.1 & 99 \\
$11 / 5$ & Serratia odorifera & NR037110.1 & 99 \\
$15 / 1$ & Lelliottia amnigena & KM114915.1 & 99 \\
$18 / 6$ & Arthrobacter arilaitensis & CP012750.1 & 99 \\
$21 / 4$ & Pseudomonas putida & GQ2008822.1 & 99 \\
\hline
\end{tabular}

$\mathrm{Na}^{+}$contents tested in salt stress wheat plants in response to ACC deaminase producing PGPR. According to the results of the analysis, the leaf $\mathrm{Na}^{+}$content increased due to increasing salt concentrations (Table 4). Bacterial applications caused reductions in $\mathrm{Na}^{+}$content compared to uninoculated control at 3.98, 7.80, $11.05 \mathrm{dS} \mathrm{m}^{-1}$ salinity levels. Application of A. arilaitensis at 7.80 and $11.05 \mathrm{dS} \mathrm{m}^{-1}$ salt levels decreased $\mathrm{Na}^{+}$ content by $32 \%$ and $10 \%$, respectively, compared to control. Likewise, application of P. putida was decreased $\mathrm{Na}^{+}$content of wheat by $26 \%$ and $\% 9$ at 7.80 and $11.05 \mathrm{dS} \mathrm{m}^{-1}$ salinity levels, respectively.

Table 4. Effect of ACC deaminase producing rhizobacteria on $\mathrm{Na}, \mathrm{K}$, and $\mathrm{Ca}$ under differents salinity levels in pot trials

\begin{tabular}{|c|c|c|c|c|}
\hline Strain & $0.95\left(\mathrm{dS} \mathrm{m}^{-1}\right)$ & $3.98\left(\mathrm{dS} \mathrm{m}^{-1}\right)$ & $7.80\left(\mathrm{dS} \mathrm{m}^{-1}\right)$ & $11.05\left(\mathrm{dS} \mathrm{m}^{-1}\right)$ \\
\hline \multicolumn{5}{|l|}{$\mathrm{Na}^{+}\left(\mathrm{mg} \mathrm{g}^{-1} \mathrm{DW}\right)$} \\
\hline Control & $0.12 \mathrm{~h}$ & $0.15 \mathrm{efg}$ & $0.22 \mathrm{~d}$ & $1.15 \mathrm{a}$ \\
\hline B. cereus & $0.12 \mathrm{~h}$ & $0.14 \mathrm{fgh}$ & $0.22 \mathrm{~d}$ & $1.13 \mathrm{a}$ \\
\hline S. odorifera & $0.12 \mathrm{~h}$ & $0.13 \mathrm{gh}$ & 0.16 ef & $1.09 \mathrm{~b}$ \\
\hline L. amnigena & $0.12 \mathrm{~h}$ & $0.13 \mathrm{fh}$ & $0.21 \mathrm{~d}$ & $1.10 \mathrm{~b}$ \\
\hline A. arilaitensis & $0.12 \mathrm{~h}$ & $0.12 \mathrm{~h}$ & 0.15 efg & $1.04 \mathrm{c}$ \\
\hline P. putida & $0.12 \mathrm{~h}$ & $0.12 \mathrm{~h}$ & 0.16 ef & $1.05 \mathrm{c}$ \\
\hline \multicolumn{5}{|l|}{$\mathrm{K}^{+}\left(\mathrm{mg} \mathrm{g}^{-1} \mathrm{DW}\right)$} \\
\hline Control & $2.09 \mathrm{bc}$ & $1.98 \mathrm{de}$ & $1.67 \mathrm{hij}$ & $1.56 \mathrm{k}$ \\
\hline B. cereus & $2.10 \mathrm{bc}$ & $2.08 \mathrm{bcd}$ & $1.77 \mathrm{gh}$ & $1.57 \mathrm{k}$ \\
\hline S. odorifera & $2.16 \mathrm{~b}$ & $2.10 \mathrm{~b}$ & $1.86 \mathrm{fg}$ & $1.57 \mathrm{k}$ \\
\hline L. amnigena & $2.18 \mathrm{~b}$ & $2.09 \mathrm{bc}$ & $1.83 \mathrm{fg}$ & $1.57 \mathrm{k}$ \\
\hline A. arilaitensis & $2.50 \mathrm{a}$ & $2.15 \mathrm{~b}$ & $1.90 \mathrm{ef}$ & $1.70 \mathrm{~h}_{1}$ \\
\hline P. putida & $2.56 \mathrm{a}$ & $2,18 \mathrm{~b}$ & $2.0 \mathrm{cde}$ & $1.61 \mathrm{ijk}$ \\
\hline \multicolumn{5}{|l|}{$\mathrm{Ca}^{+2}\left(\mathrm{mg} \mathrm{g}^{-1} \mathrm{DW}\right)$} \\
\hline Control & 0.80 abcd & 0.74 efg & $0.69 \mathrm{~g}$ & $0.57 \mathrm{~h}$ \\
\hline B. cereus & 0.80 abcd & $0.80 \mathrm{abcd}$ & $0.71 \mathrm{fg}$ & $0.59 \mathrm{~h}$ \\
\hline S. odorifera & $0.85 \mathrm{a}$ & 0.77 bcde & $0.69 \mathrm{~g}$ & $0.58 \mathrm{~h}$ \\
\hline L. amnigena & $0.82 \mathrm{ab}$ & $0.81 \mathrm{abc}$ & $0.75 \mathrm{def}$ & $0.59 \mathrm{~h}$ \\
\hline A. arilaitensis & $0.82 \mathrm{ab}$ & $0.82 \mathrm{ab}$ & 0.77 bcde & $0.70 \mathrm{fg}$ \\
\hline P. putida & $0.84 \mathrm{a}$ & 0.77 bcde & 0.77 bcde & $0.69 \mathrm{~g}$ \\
\hline
\end{tabular}

$\mathrm{p}<0.05$ bacteria $*$, salinity $*$, bacteriaxsalinity ${ }^{*}$ values with the same letter are not different according to DUNCAN

Leaf $\mathrm{K}^{+}$content decreased due to increased salt concentrations in trials (Table 4). Bacterial applications containing ACC deaminase were found to increase leaf $\mathrm{K}^{+}$ content $0.95,3.98,7.80,11.05 \mathrm{dS} \mathrm{m}^{-1}$ salinity levels compared to control. Application of $P$. putida increased leaf $\mathrm{K}^{+}$content at $3.98,7.80,11.05 \mathrm{dS} \mathrm{m}^{-1}$ salinity levels by $10 \%$, 
$20 \%$ and $4 \%$, respectively. Similarly, application of A. arilaitensis increased $9 \%, 14 \%$ and $9 \% \mathrm{~K}^{+}$content at $3.98,7.80,11.05 \mathrm{dS} \mathrm{m}^{-1}$ salinity levels, respectively.

Leaf $\mathrm{Ca}^{+2}$ content decreased due to increased salt concentrations similar to $\mathrm{K}^{+}$ content. Bacterial applications increased $\mathrm{Ca}^{+2}$ content at, 3.98, 7.80, $11.05 \mathrm{dS} \mathrm{m}^{-1}$ salinity levels over the uninoculated control. The maximum $\mathrm{Ca}^{+2}$ increases data obtained from $A$. arilaitensis application at 3.98, 7.80, $11.05 \mathrm{dS} \mathrm{m}^{-1}$ salinity levels by $9 \%, 9 \%$ and $22 \%$, respectively.

Chlorophyll a content of wheat significantly affected salinity (Table 5). Depending on the salt level, chlorophyll a content significantly decreased. ACC deaminase producing PGPR applications did not affect chlorophyll a content at $0.95 \mathrm{dS} \mathrm{m}^{-1}$ salinity levels. However, bacterial applications increased chlorophyll a content compared to control at 3.98, 7.80, $11.05 \mathrm{dS} \mathrm{m}^{-1}$ salinity levels. Application of P. putida increased chlorophyll a content at 3.98, 7.80, $11.05 \mathrm{dS} \mathrm{m}^{-1}$ salinity levels by $4 \%, 7 \%$ and $10 \%$, respectively.

Table 5. Effect of ACC deaminase producing rhizobacteria on chlorophyll a content of wheat under different salinity levels in pot trials $\left(\mathrm{mg} \mathrm{g}^{-1} \mathrm{FW}\right)$

\begin{tabular}{|c|c|c|c|c|c|}
\hline Strain & $0.95\left(\mathrm{dS} \mathrm{m}^{-1}\right)$ & $3.98\left(\mathrm{dS} \mathrm{m}^{-1}\right)$ & $7.80\left(\mathrm{dS} \mathrm{m}^{-1}\right)$ & $11.05\left(\mathrm{dS} \mathrm{m}^{-1}\right)$ & Avarage \\
\hline Control & 1.95 & 1.80 & 1.73 & 1.60 & $1.77 \mathrm{~b}$ \\
\hline B. cereus & 1.94 & 1.83 & 1.76 & 1.73 & $1.82 \mathrm{ab}$ \\
\hline S. odorifera & 1.94 & 1.85 & 1.77 & 1.72 & $1.82 \mathrm{a}$ \\
\hline L. amnigena & 1.94 & 1.87 & 1.77 & 1.74 & $1.83 \mathrm{a}$ \\
\hline A. arilaitensis & 1.98 & 1.89 & 1.82 & 1.75 & $1.86 \mathrm{a}$ \\
\hline P. putida & 1.97 & 1.89 & 1.84 & 1.75 & $1.86 \mathrm{a}$ \\
\hline Average & $1.95 \mathrm{a}$ & $1.86 \mathrm{~b}$ & $1.78 \mathrm{c}$ & $1.72 \mathrm{~d}$ & \\
\hline
\end{tabular}

$\mathrm{p}<0.05$ bacteria *, salinity *, bacteriaxsalinity ${ }^{\text {n.s. }}$ values with the same letter are not different according to DUNCAN

Chlorophyll $\mathrm{b}$ content of wheat significantly decreased due to salinity application (Table 6). Bacteria applications did not affect chlorophyll b content at $0.95 \mathrm{dS} \mathrm{m}^{-1}$ salinity levels. Contrary to the $0.95 \mathrm{dS} \mathrm{m}^{-1}$ salinity levels, the amount of chlorophyll $\mathrm{b}$ increased with the application of ACC deaminase producing PGPR at 3.98, 7.80, $11.05 \mathrm{dS} \mathrm{m} \mathrm{m}^{-1}$ salinity levels. A. arilaitensis application increased the amount of chlorophyll b by $15 \%$ on average.

Table 6. Effect of ACC deaminase producing rhizobacteria on chlorophyll $b$ content of wheat under different salinity levels in pot trials $\left(\mathrm{mg} \mathrm{g}^{-1} \mathrm{FW}\right)$

\begin{tabular}{|c|c|c|c|c|c|}
\hline Strain & $0.95\left(\mathrm{dS} \mathrm{m}^{-1}\right)$ & $3.98\left(\mathrm{dS} \mathrm{m}^{-1}\right)$ & $7.80\left(\mathrm{dS} \mathrm{m}^{-1}\right)$ & $11.05\left(\mathrm{dS} \mathrm{m}^{-1}\right)$ & Avarage \\
\hline Control & 1.42 & 1.00 & 0.78 & 0.60 & $0.95 \mathrm{c}$ \\
\hline B. cereus & 1.46 & 1.07 & 0.89 & 0.71 & $1.03 b c$ \\
\hline S. odorifera & 1.46 & 1.02 & 0.91 & 0.71 & $1.03 \mathrm{bc}$ \\
\hline L. amnigena & 1.43 & 1.04 & 0.96 & 0.84 & $1.07 \mathrm{ab}$ \\
\hline A. arilaitensis & 1.48 & 1.07 & 0.99 & 0.86 & $1.10 \mathrm{a}$ \\
\hline P. putida & 1.46 & 1.07 & 0.98 & 0.79 & $1.08 \mathrm{ab}$ \\
\hline Average & $1.45 \mathrm{a}$ & $1.5 \mathrm{~b}$ & $0.92 \mathrm{c}$ & $0.75 \mathrm{~d}$ & \\
\hline
\end{tabular}

$\mathrm{p}<0.05$ bacteria *, salinity *, bacteriaxsalinity ${ }^{\text {n.s. }}$ values with the same letter are not different according to DUNCAN 


\section{Discussion}

In this study, 21 ACC deaminase containing PGPR isolated from the wheat root rhizosphere and plant growth-promoting activities of isolates tested under salt stress condition by petri trials. Based on petri trials, jar trials and according to the results of the jar trials pot trials conducted. The effect of five ACC deaminase containing PGPR (B. cereus, S. odorifer, L. amnigena, A. arilaitensis, $P$. putida) was evaluated for wheat growth and yield under salt stress $0.95,3.98,7.80,11.05 \mathrm{dS} \mathrm{m}{ }^{-1}$ salinity levels in pot trials. The results showed that salt stress had a strong negative effect on the development of wheat plants, while ACC deaminase containing bacterial applications increased wheat development. Previously conducted studies showed that several bacteria species, including Serratia and Pseudomonas (Zahir et al., 2009), Arthrobacter (Barnawal et al., 2014), Streptomyces (Palaniyandi et al., 2014), Enterobacter (Singh et al., 2016), Staphylococcus and Kocuria (Yildirim et al., 2011), Cronobacter (Afridi et al., 2019), increased plant growth under salt-stress conditions.

ACC deaminase containing bacterial applications increased the root and shoot length of wheat under saline conditions in petri $\left(5 \mathrm{dS} \mathrm{m}^{-1}\right)$ and jar $\left(10 \mathrm{dS} \mathrm{m}^{-1}\right)$ trials. Inoculation of rhizobacteria strains promoted root and shoot growth by lowering levels of ethylene caused by salt stress. It is known as the ethylene stress hormone and its synthesis is accelerated in response to different environmental stresses like salinity (Mayak et al., 2004). It has been shown that ACC-deaminase containing PGPR can help regulate endogenous ethylene levels in plants through ACC-deaminase activities and consequently promote plant growth and development (Maqshoof et al., 2011; Glick, 2014; Shimaila et al., 2014; Khan et al., 2016; Barra et al., 2016; Sarkar et al., 2018; Afridi et al., 2019). Higher concentrations of ethylene reduced plant growth. In this study, B. cereus, S. odorifer, L. amnigena, A. arilaitensis, P. putida exhibited ACC deaminase production, which cleaved ACC into $\alpha$-ketobutyrate and ammonia and reduces the harsh effects of ethylene on plant growth under salinity stress.

Ionic balance is disturbed in plants under saline conditions. Salinity leads to reducing plant growth and development, as well as impairment of ionic balance, especially $\mathrm{Na}^{+}$ and $\mathrm{K}^{+}$(Singh et al., 2016). One of the effects of salinity is that the high $\mathrm{Na}^{+}$content has an antagonistic effect on $\mathrm{K}^{+}$uptake. Therefore, restricting $\mathrm{Na}^{+}$intake by increasing $\mathrm{K}^{+}$ intake are the main strategies commonly used by plants to maintain the desired $\mathrm{K}^{+} / \mathrm{Na}^{+}$ ratio in the cytosol (Khan et al., 2009). In this study, $\mathrm{Na}^{+}$increased and $\mathrm{K}^{+}$decreased in plants due to increasing salt concentrations. However, in the application of bacteria that contain acc deaminase, the amount of $\mathrm{Na}^{+}$in the plant has decreased and the amount of $\mathrm{K}^{+}$has increased. Application of $A$. arilaitensis, and $P$. putida especially may help to ion homeostasis of wheat in pot trials. Also, the inoculation of bacteria increased $\mathrm{Ca}^{+2}$ content that improves plant growth. According to Zahir et al. (2009), low $\mathrm{Na}^{+}$uptake by grafted roots likely resulted from the reduction of $\mathrm{Na}^{+}$passive (apoplastic) flow into tissues caused by a higher proportion of the root covered with soil. Likewise, this effect has been reported in studies conducted with wheat (Singh et al., 2016, 2017; Afridi et al., 2019) and maize (El-Komy, 1998). Yue et al. (2007), Shimaila et al. (2014) and Turhan et al. (2020) shown in their studies that the plants inoculated with ACC deaminase containing bacteria have a low $\mathrm{Na}^{+}$and high $\mathrm{K}^{+}$content.

The decrease in photosynthetic efficiency takes an important place in salinity decreasing plant growth and productivity (Colmenero-Flores et al., 2007). The lack of physiological water caused by salinity stress reduces stomatal conductivity and slows down $\mathrm{CO}_{2}$ assimilation (James et al., 2002). PGPR has an important role in increasing 
the water intake in salt conditions and reducing the suppression of photosynthesis under salinity stress (Hashem et al., 2019). In this study, the amount of chlorophyll a and chlorophyll $b$ decreased in salt stress conditions. On the contrary, ACC deaminase containing bacterial applications increased the amount of chlorophyll a and b compared to the uninoculated control. The findings obtained in this study are compatible with previous studies reporting an increase in photosynthetic activity in plants inoculated with ACC deaminase-producing PGPR (Singh et al., 2016, 2017; Chen et al., 2017; Afridi et al., 2019).

\section{Conclusion}

As a result, the results show that salt stress applied to wheat has strong negative effects on the growth of wheat. However, inoculation with B. cereus, S. odorifer, L. amnigena, A. arilaitensis, $P$. putida has a positive effect on the development of wheat plants under salt stress conditions. The results of the study show that ACC deaminase containing bacterial inoculation supports stress tolerance to wheat plants in terms of plant growth and biochemistry. For this reason, use of ACC deaminase containing bacteria great hope for the plant growth promote in saline soils. Therefore, using ACC deaminase containing bacteria to increase plant growth in saline soils is an environmentally friendly and economical option. However, this study was carried out under controlled conditions in the greenhouse. Therefore, in future studies, it will be useful to determine the yield and quality parameters of wheat in, the field conditions especially inoculation with $A$. arilaitensis, $P$. putida. In addition, suitable carrier formulations for bacteria need to be studied.

\section{REFERENCES}

[1] Afridi, M. S., Amna, S., Tariq, M., Abdul, S., Tehmeena, M., Shehzad, M. (2019): Induction of Tolerance to Salinity in Wheat Genotypes by Plant Growth Promoting Endophytes: Involvement of ACC Deaminase and Antioxidant Enzymes. - Plant Physiology and Biochemistry 139(4): 569-77.

[2] Ali, S., Kim, W.-C. (2018): Plant Growth Promotion under Water: Decrease of Waterlogging-Induced ACC and Ethylene Levels by ACC Deaminase-Producing Bacteria. - Frontiers in Microbiology 9: 1096.

[3] Barnawal, D., Nidhi, B., Deepamala, M., Chandan, S. C., Alok, K. (2014): ACC Deaminase-Containing Arthrobacter Protophormiae Induces $\mathrm{NaCl}$ Stress Tolerance through Reduced ACC Oxidase Activity and Ethylene Production Resulting in Improved Nodulation and Mycorrhization in Pisum Sativum. - Journal of Plant Physiology 171(11): 884-94.

[4] Barra, P. J., Inostroza, N. G., Acuña, J. J., Mora, M. L., Crowley, D. E., Jorquera, M. A. (2016): Formulation of Bacterial Consortia from Avocado (Persea Americana Mill.) and Their Effect on Growth, Biomass and Superoxide Dismutase Activity of Wheat Seedlings under Salt Stress. - Applied Soil Ecology 102: 80-91.

[5] Çakmakçı, R. (2016): Screening of Multi-Trait Rhizobacteria for Improving the Growth, Enzyme Activities, and Nutrient Uptake of Tea (Camellia Sinensis). - Communications in Soil Science and Plant Analysis 47(13-14): 1680-90.

[6] Carlson, R., Tugizimana, F., Steenkamp, P. A., Dubery, I. A., Hassen, A. I., Labuschagne, N. (2020): Rhizobacteria-Induced Systemic Tolerance against Drought Stress in Sorghum Bicolor (L.) Moench. - Microbiological Research 232: 126388. 
[7] Chen, C. Q., Xin, K. Y., Liu, H., Cheng, J. L., Shen, X. H., Wang, Y., Zhang, L. (2017): Pantoea Alhagi, a Novel Endophytic Bacterium with Ability to Improve Growth and Drought Tolerance in Wheat. - Scientific Reports 7(1): 1-14.

[8] Colmenero-Flores, J. M., Martínez, G., Gamba, G., Vázquez, N., Iglesias, D. J., Brumós, J., Talón, M. (2007): Identification and Functional Characterization of Cation-Chloride Cotransporters in Plants. - Plant Journal 50(2): 278-92.

[9] Dworkın, M., Foster, J. W. (1958): Experiments with Some Microorganisms Which Utilize Ethane and Hydrogen. - Journal of Bacteriology 75(5): 592-603.

[10] El-Komy, M. A., Hamdia, M. A. (1997): Effect of salinity, gibberellic acid and Azospirillum inoculation on growth and nitrogen uptake of Zea mays. - Biologia plantarum 40(1): 109-120.

[11] Erdogan, Ü., Ramazan, Ç., Atafeh, V., Metin, T., Yaşar, E., Kıtır, N. (2016): Role of Inoculation with Multi-Trait Rhizobacteria on Strawberries under Water Deficit Stress. Zemdirbyste-Agriculture 103(1): 67-76.

[12] Glick, B. R. (2014): Bacteria with ACC Deaminase Can Promote Plant Growth and Help to Feed the World. - Microbiological Research 169(1): 30-39.

[13] Grobelak, A., Kokot, P., Swiatek, J., Jaskulak, M., Rorat, A. (2018): Bacterial ACC Deaminase Activity in Promoting Plant Growth on Areas Contaminated with Heavy Metals. - Journal of Ecological Engineering 19(5): 150-57.

[14] Hashem, A., Abd_Allah, E. F., Alqarawi, A. A., Wirth, S., Egamberdieva, D. (2019): Comparing Symbiotic Performance and Physiological Responses of Two Soybean Cultivars to Arbuscular Mycorrhizal Fungi under Salt Stress. - Saudi Journal of Biological Sciences 26(1): 38-48.

[15] Hassan, W., Bashir, S., Ali, F., Ijaz, M., Hussain, M., David, J. (2016): Role of ACCDeaminase and/or Nitrogen Fixing Rhizobacteria in Growth Promotion of Wheat (Triticum Aestivum L.) under Cadmium Pollution. - Environmental Earth Sciences 75(3): $1-14$.

[16] Hoagland, D. R., Arnon, D. I. (1950): The water: culture method for growing plants without soil. - California Agricultural Experiment Station, Berkeley.

[17] James, R. A., Rivelli, A. R., Munns, R., Von Caemmerer, S. (2002): Factors Affecting CO2 Assimilation, Leaf Injury and Growth in Salt-Stressed Durum Wheat. - Functional Plant Biology 29(12): 1393-1403.

[18] Khan, M. A., Shirazi, M. U., Khan, M. A., Mujtaba, S. M. (2009): Role of Proline, K / Na Ratio and Chlorophyll Content in Salt Tolerance of Wheat. - Pakistan Journal of Botany 41(2): 633-38.

[19] Khan, A. S., Xue, Q. Z., Mohammed, T. J., Khalid, S. K., Asghari, B., Ren, F. S., Sajid, M. (2016): Bacillus pumilus Enhances Tolerance in Rice (Oryza Sativa L.) to Combined Stresses of $\mathrm{NaCl}$ and High Boron Due to Limited Uptake of $\mathrm{Na}^{+}$. - Environmental and Experimental Botany 124: 120-29.

[20] Lichtenthaler, H. K. (1987): Chlorophylls and Carotenoids: Pigments of Photosynthetic Biomembranes. - Methods in Enzymology 148(C): 350-82.

[21] Maqshoof, A., Zahir, A., Zahir, H., Naeem, A., Asghar, M. (2011): Inducing Salt Tolerance in Mung Bean through Coinoculation with Rhizobia and PlantGrowthpromoting Rhizobacteria Containing 1-Aminocyclopropane-1-Carboxylate Deaminase. - Canadian Journal of Microbiology 57(7): 578-89.

[22] Mayak, S., Tsipora, T., Glick, B. R. (2004): Plant Growth-Promoting Bacteria Confer Resistance in Tomato Plants to Salt Stress. - Plant Physiology and Biochemistry 42(6): 565-72.

[23] Munns, R., Tester, M. (2008): Mechanisms of Salinity Tolerance. - Annual Review of Plant Biology 59(1): 651-81.

[24] Nadeem, S. M., Zahir, A. Z., Muhammad, N., Hafiz, N. A., Muhammad, A. (2010): Rhizobacteria Capable of Producing ACC-Deaminase May Mitigate Salt Stress in Wheat. - Soil Science Society of America Journal 74(2): 533-42. 
[25] Palaniyandi, S. A., Damodharan, K., Yang, S. H., Suh, J. W. (2014): Streptomyces Sp. Strain PGPA39 Alleviates Salt Stress and Promotes Growth of 'Micro Tom' Tomato Plants. - Journal of Applied Microbiology 117(3): 766-73.

[26] Parihar, P., Samiksha, S., Rachana, S., Vijay, P. S., Sheo, M. P. (2015): Effect of Salinity Stress on Plants and Its Tolerance Strategies: A Review. - Environmental Science and Pollution Research 22(6): 4056-75.

[27] Rajput, L., Asma, I., Fathia, M., Fauzia, Y. H. (2013): Salt-Tolerant PGPR Strain Planococcus Rifietoensis Promotes the Growth and Yield of Wheat (Triticum Aestivum L.) Cultivated in Saline Soil. - Pakistan Journal of Botany 45(6): 1955-62.

[28] Ravanbakhsh, M., Sasidharan, R., Voesenek, L. A. C. J., Kowalchuk, G. A., Jousset, A. (2017): ACC Deaminase-Producing Rhizosphere Bacteria Modulate Plant Responses to Flooding. - Journal of Ecology 105(4): 979-86.

[29] Sarkar, A., Pallab, K. G., Krishnendu, P., Soumik, M., Tithi, S., Sanjeev, P., Monohar, H. M., Tushar, K. M. (2018): A Halotolerant Enterobacter Sp. Displaying ACC Deaminase Activity Promotes Rice Seedling Growth under Salt Stress. - Research in Microbiology 169(1): 20-32.

[30] Shanmugam, V., Kanoujia, N. (2011): Biological Management of Vascular Wilt of Tomato Caused by Fusarium oxysporum f. Sp. Lycospersici by Plant Growth-Promoting Rhizobacterial Mixture. - Biological Control 57(2): 85-93.

[31] Shimaila, A., Charles, T. C., Glick, B. R. (2014): Amelioration of High Salinity Stress Damage by Plant Growth-Promoting Bacterial Endophytes That Contain ACC Deaminase. - Plant Physiology and Biochemistry 80(6): 160-67.

[32] Singh, R. P., Prabhat, N. J. (2016): Mitigation of Salt Stress in Wheat Plant (Triticum Aestivum) by ACC Deaminase Bacterium Enterobacter Sp. SBP-6 Isolated from Sorghum Bicolor. - Acta Physiologiae Plantarum 38: 110.

[33] Singh, R. P., Prameela, J., Prabhat, N. J. (2017): Bio-Inoculation of Plant GrowthPromoting Rhizobacterium Enterobacter cloacae ZNP-3 Increased Resistance Against Salt and Temperature Stresses in Wheat Plant (Triticum Aestivum L.). - Journal of Plant Growth Regulation 36(3): 783-98.

[34] Sofo, A., Scopa, A., Nuzzaci, M., Vitti, A. (2015): Ascorbate Peroxidase and Catalase Activities and Their Genetic Regulation in Plants Subjected to Drought and Salinity Stresses. - International Journal of Molecular Sciences 16(6): 13561-78.

[35] Tahir, M., Ahmad, I., Shahid, M., Shah, G. M., Farooq, A. B. U., Akram, M., Tabassum, S. A., Naeem, M. A., Khalid, U., Ahmad, S., Zakir, A. (2019): Regulation of Antioxidant Production, Ion Uptake and Productivity in Potato (Solanum Tuberosum L.) Plant Inoculated with Growth Promoting Salt Tolerant Bacillus Strains. - Ecotoxicology and Environmental Safety 178(4): 33-42.

[36] Tester, M. (2003): $\mathrm{Na}^{+}$Tolerance and $\mathrm{Na}^{+}$Transport in Higher Plants. - Annals of Botany 91(5): 503-27.

[37] Turhan, E., Kıran, S., Ates, Ç., Ates, O., Sebnem, K., Sekure, S. E. (2020): Ameliorative Effects of Inoculation with Serratia marcescens and Grafting on Growth of Eggplant Seedlings under Salt Stress. - Journal of Plant Nutrition 43(4): 594-603.

[38] Yang, C. W., Wang, P., Li, C. Y., Shi, D. C., Wang, D. L. (2008): Comparison of Effects of Salt and Alkali Stresses on the Growth and Photosynthesis of Wheat. Photosynthetica 46(1): 107-14.

[39] Yildirim, E., Turan, M., Ekinci, M., Dursun, A., Cakmakci, R. (2011): Plant Growth Promoting Rhizobacteria Ameliorate Deleterious Effect of Salt Stress on Lettuce. Scientific Research and Essays 6(20): 4389-96.

[40] Yue, H. T., Mo, W. P., Li, C., Zheng, Y. Y., Li, H. (2007): The Salt Stress Relief and Growth Promotion Effect of Rs-5 on Cotton. - Plant and Soil 297(1-2): 139-45.

[41] Zahir, Z. A., Ghani, U., Naveed, M., Nadeem, S. M., Asghar, H. N. (2009): Comparative Effectiveness of Pseudomonas and Serratia Sp. Containing ACC-Deaminase for 
Improving Growth and Yield of Wheat (Triticum Aestivum L.) under Salt-Stressed Conditions. - Archives of Microbiology 191(5): 415-24.

[42] Zelicourt, de A., Al-Yousif, M., Hirt, H. (2013): Rhizosphere Microbes as Essential Partners for Plant Stress Tolerance. - Molecular Plant 6(2): 242-45. 